\title{
OBITUARY
}

\section{J. G. GREENFIELD, M.D., B.Sc., LL.D.Edin., F.R.C.P.}

Dr. J. Godwin Greenfield died suddenly, aged 73, on March 1, 1958, at Bethesda, Maryland, U.S.A., where he had spent many months each year for a number of years since he retired from the National Hospital, Queen Square, London.

He was born in Edinburgh, where his father, W. S. Greenfield, was professor of pathology and clinical medicine. There too he was educated, both at school and at the University, where he qualified in 1908. During his period of medical education he was distinguished for his prowess not only at work but also at play, for he was a University golfer, and he continued this form of exercise throughout his active life. After two years as house physician at the National Hospital, he went to Leeds General Infirmary as an assistant pathologist, where he came under the influence of Professor Matthew Stewart. He returned as pathologist to the National Hospital, but almost at once he enlisted in the R.A.M.C., and served during the 1914-18 war in Belgium and France. Later he went to Tooting Hospital, where he did valuable neuropathological work.

Returning in 1919 to Queen Square to resume his appointment, he continued for the next 30 years as pathologist to that hospital, apart from a spell of work in the Emergency Medical Service at Chase Farm Hospital during World War II.

He retired officially in 1949 , but for the next few years he continued with research work at Queen Square and also commenced writing the volume on neuropathology which has now been published.

Greenfield received an invitation to go to America, and for the past three years he spent part of each year at the National Institute of Neurological Diseases and Blindness at Bethesda. This proved to be a great joy to him, for not only had he considerable opportunities but every facility of that Institute was placed at his disposal, including a flat for himself and for Mrs. Greenfield, who accompanied him on each occasion.

He wrote extensively, chiefly on neurological subjects, and many are the erudite articles he contributed to journals such as Brain. He was co-editor with Arnold Carmichael of the well-known book on the cerebrospinal fluid, and with Farquhar Buzzard wrote a small book on neuropathology. More recently a monograph on spinocerebellar degenerations was published, and with some American colleagues a volume on muscle diseases appeared, both of which were received with well-deserved compliments by reviewers.

Many were the honours so rightly bestowed on him. Lectures he gave included the OliverSharpey, the Morison, the Hughlings Jackson, and not least the second Dyke Foundation lecture of the Association of Clinical Pathologists. $\mathrm{He}$ was the recipient of an honorary LL.D. of Edinburgh given to him by the hand of the Duke of Edinburgh, as he then was. At this magnificent ceremony, which I was privileged to attend, he showed his typical modesty, and later his great pleasure at this honour in his home town.

Greenfield was a founder member in 1927 of the Association of Clinical Pathologists, and was immediately elected to the Council. The following year he became vice-president, in which capacity he served five years. He became President in 1934, holding that office for three years. He then returned to the Council for four years, and in 1948 he was appointed to the Editorial Board of the Journal of Clinical 
Pathology, on which board he remained for nine years, retiring only one year ago. Throughout this long period Greenfield worked quietly but continuously to further the work of the Association, for, although the foremost neuropathologist in this country, yet he was a typical example of a real clinical pathologist. His knowledge of general pathology was very wide and he was an extremely able general histologist, as I know from personal experience. He gave of his knowledge and wisdom not only to the Association but also to the Consulting Pathologists Group of the British Medical Association.

Towards the end of his life he founded the Neuropathological Club in an endeavour to aid the many younger members who were interested in this subject, and this club included overseas as well as British members. This thought was typical of his interest in others and for the welfare and encouragement of the more youthful pathologist.

I first met Greenfield in 1933 when he was an acknowledged master, yet his modesty, sincerity, and kindness towards his new and young assistant pathologist was something that will never be forgotten. Further, his manner of teaching, his methods of guidance and direction, were not lost upon the many with whom he came in contact. Always enthusiastic, always helpful, he would assist in whatever was necessary, even to the cutting of his own histological sections, for in this too he was an expert. The very many postgraduate students who came to work under him were impressed not only by his knowledge but also by the inherent friendliness of a very human man, and many have continued in correspondence with him throughout the years. Housemen and postgraduate students were invited to play tennis with him at the weekends, and at Christmas there was always the exchange of gifts. In later years, after he moved to Surrey, many friends of all age groups visited the Greenfields and were entertained by them. He enjoyed showing them round his garden, for there he spent much time working hard and finding great pleasure in the fruits of his labours. He was, as well as being a gardener, a keen photographer, and, while colour transparencies were his favourites, his Christmas cards of recent years have usually been decorated by a black and white landscape taken by him during the year.

Despite osteoarthritis of the hip he continued to enjoy life to the full and it appeared as though he would be working for many more years.

It is with much sorrow that we lament his passing. but we are very grateful to have known and worked with him. It will be extremely difficult to fill the gap caused by his death either in the Association or in neuropathology.

JoHN N. CUMings.

\section{ALFRED S. GIORDANO}

Alfred S. Giordano was elected to honorary membership of the Association of Clinical Pathologists in 1930 when the total membership numbered but 82 . At that time he was unknown to us except as the secretary of our counterpart society in the United States which had come into existence four years before ours and which by then was already well established.

Alfred Giordano was born in Avellino, Italy, in 1893, and at the age of 4 was taken to Syracuse, New York, where he went to high school and subsequently to the university, qualifying there in 1920 . After

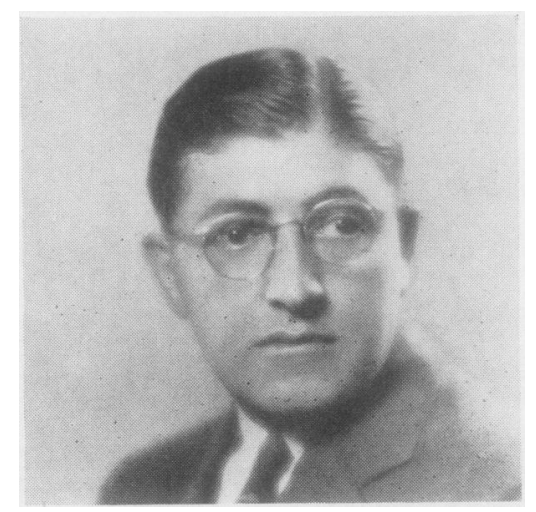

spending three years in postgraduate study at the Mayo Clinic he was appointed pathologist to the South Bend Medical Laboratory, a diagnostic centre established in 1912 by a group of far-sighted practitioners and housed at that time in the Epworth (now the Memorial) Hospital. In this pleasant industrial town of some 115,000 inhabitants, he spent his whole professional life, and at the time of his retirement in 1952 this unit had grown under his able direction from a single room in a basement manned by one technician and himself to a well-equipped institute and associated hospital laboratories with a medical staff of seven and a technical staff of 75 . In 1946 the $N$ central laboratory became the South Bend Medical i Institution, a non-profit-making diagnostic and $\mathrm{N}$ research organization, and now a permanent memorial $\omega$ of his vision and enterprise.

And here it was in this model laboratory that Jerry Giordano made everyone feel welcome. After a visit to the Foundation the traveller from abroad would be taken to his lovely home set in a wooded garden sloping steeply down to a picturesque bend on the St. Joseph river. After a serious illness in 1948 he was compelled to abandon this delectable home in favour of a single-storied house on level ground, but here too 